2. Белінська О. В. Медіація - альтернативне вирішення спорів. Вісник Вищої ради юстииї̈. 2011. № 1(5). С. 158-173.

3. Єрьоменко Г. Перспективи розвитку медіації в Україні. URL: http://www.ukrmediation.com.ua/files/content/Perspectyvy.pdf (дата звернення: 04.10.2020).

4. Кафарський В. В. Медіація в адміністративному судочинстві. Прикарпатський юридичний вісник. 2014. Вип. 3(6). С. 152-165.

5. Срьоменко Г. Медіація - альтернативний спосіб розв'язання конфліктів, або і вівці цілі, і вовки не голодні. Маркетинг в Украйні. 2011. № 5. C. 67-70.

DOI https://doi.org/10.30525/978-9934-588-92-1-53

\title{
ДОВІРА ДО ВЛАДИ В СИСТЕМІ ЗАХИСТУ ІНТЕРЕСІВ ГРОМАДЯН
}

\author{
Булгакова О. В. \\ кандидат економічних наук, дочент, \\ дочент кафедри державно-правових дисииллін \\ Донецького юридичного інституту \\ Міністерства внутрішніх справ Украӥни \\ м. Кривий Ріг, Дніпропетровська область, Україна
}

Сучасна практика управління за умови демократизації суспільного життя і розвитку ринкової економіки стикається з питаннями мало ефективності сталих традиційних організаційно-управлінських засобів і заходів та порушує питання про необхідність пошуку нових шляхів вирішення питань в управлінні та запровадження нових форм урядування, які здатні вирішувати складні сучасні проблеми. В складній системі суспільства урядування можна розглянути як застосування економічної, політичної та адміністративної влади для досягнення успіху в реалізації задач державного управління на всіх рівнях. Таке урядування охоплює механізми, процедури та інституції, за допомогою яких громадяни та певні групи громадян здатні висловлювати та реалізовувати свої інтереси, реалізовувати в повному обсязі свої юридичні права та врегульовувати суперечності [1, с. 103].

Складно заперечити, що однією 3 найважливіших проблем сучасного розвитку суспільства $є$ питання ефективності взаємовідносин 218 
держави та громадянина, які реалізуються через національні та міжнародні механізми забезпечення прав і свобод людини. Розвиток громадянського суспільства в Україні стає можливим через запити суспільства не тільки на однобічний захист прав і свобод людини 3 боку держави, а й на забезпечення функціонування дієвих механізмів, які дозволяють громаді мати публічний контроль влади щодо виконання державницьких обов'язків. Система публічного управління громади, як основне джерело влади, формує певний рівень довіри до влади, який формується під впливом багатьох чинників та $\epsilon$ комплексним показником якості державного управління щодо задоволення потреб людей в реалізації та захисті їх прав та задоволенні потреб на особистий та суспільний розвиток [1, с. 103].

Об’єктивна закономірність розвитку цивілізації це визнання пріоритету соціальних аспектів, сукупність тенденцій і пропорцій, які формують соціальну сферу та здатне визначати якісну характеристику життя людини в суспільстві. Економічна парадигма, яка була панівною протягом попередніх десятиліть у вітчизняній і світовій управлінських системах, концентрувала увагу переважно на матеріально-речових аспектах суспільного життя людини, надаючи саме їм домінантного значення в процесі суспільного розвитку [2, с. 85].

Одночасно з цим досвід багатьох країн засвідчує, що кількісно швидкий економічний зріст не здатен забезпечити якісне задоволення основних матеріальних потреб значної кількості людей, не здатне створити сприятливий соціально-духовний та морально-ціннісний клімат, не здатен розв'язати або усунути проблеми екології, розвитку культури, освіти, особистої безпеки і суспільної моралі. Тож можна сказати, що економічне збільшення вартості матеріальних цінностей не забезпечує автоматичного досягнення підвищення якості життя [2, с. 85].

Сучасний науковий підхід формує новий погляд на вирішення проблем досягнення ефективності в управлінні. В цьому питанні цільовим орієнтиром економічного та соціального розвитку стає саме розв'язання проблем соціальної активності людини, соціальних груп, суспільства в цілому. Основним стратегічним завданням державного управління стає формування такої моделі добробуту населення, яка здатна забезпечити людині і адекватне економічне забезпечення, i відповідний рівень соціальної реалізації. Тож за умов розвитку громадянського суспільства це завдання реалізується через забезпечення законодавчих, організаційних, економічних та інших умов для цього. Розуміння концепції сучасної сервісної держави як такої, що надає послуги особі (громадянину) та суспільству в цілому, а 
також системи владних інститутів як системи надання послуг, набуває якісно нового значення.

Відповідно до Концепції розвитку системи надання адміністративних послуг органами виконавчої влади передбачалось, що розвиток системи надання адміністративних послуг [3] повинен здійснюватися 3 урахуванням таких основних принципів:

- доступність послуг для всіх фізичних та юридичних осіб;

- дотримання стандартів надання послуг;

- відповідність розміру плати за послуги економічно обгрунтованим витратам, пов'язаним з їх наданням;

- відкритість.

Доступність послуг $є$ тим пунктом у формуванні довіри до адміністративної влади, який досягається через розвиток інформаційних сайтів відповідних адміністративних органів, створення прозорих офісів та стандартизацією надавання відповідних послуг.

Також Концепція розвитку системи надання адміністративних послуг [3] регламентувала що для забезпечення розвитку системи надання адміністративних послуг необхідно розв'язати такі проблеми:

- наявність не передбачених законами видів адміністративних послуг;

- поділ адміністративної послуги на кілька платних послуг;

- перекладення обов'язків адміністративних органів із збирання довідок або погодження документів на фізичних та юридичних осіб;

- вимагання від фізичних та юридичних осіб документів, не визначених законодавством або у не передбаченій законодавством формі;

- необгрунтоване справляння плати або необгрунтовано великі розміри плати за надання окремих видів адміністративних послуг;

- встановлення в адміністративному органі графіка приймання громадян у незручний для них час;

- необгрунтовано тривалий строк надання окремих послуг;

- обмеженість доступу до інформації, необхідної для отримання адміністративних послуг;

- неналежне законодавче регулювання процедурних питань надання послуг;

- фактичне зобов'язування фізичних та юридичних осіб отримувати супутні платні послуги;

- віднесення до повноважень одного органу здійснення контролю i надання відповідних послуг;

- відсутність стандартів надання послуг; 
- ставлення до фізичних та юридичних осіб як до прохачів, орієнтація не на задоволення потреб особи, а на формальне дотримання процедури.

Аналіз цього переліку дає змогу виокремити три основних групи проблем, пов'язаних із захистом інтересів громадян, а саме

1. Існування чіткого переліку необхідних адміністративних послуг;

2. Публічна економічно обгрунтована тарифікація плати за адміністративні послуги;

3. Стандартизація процедури надання послуги щодо умов, строків та залученості громадян в технологію отримання адміністративної послуги.

Довіра до влади в громадянському суспільстві формується за умови наявності максимальної готовності та здатності органів адміністративної влади забезпечувати умови реалізацію потреб громадян. В цьому аспекті механізм надання адміністративних послуг, який повинен бути максимально зрозумілим для кожного громадянина та може бути реалізованим державним службовцем за передбачуваним стандартом, набуває вагомості в підвищенні рівня довіри до дій владних органів.

В той же час слід констатувати, що пересічний українець сьогодні $є$ носієм «культури недовіри» до влади, яка характеризується слабкою залученістю до функціонування і контролю інститутів політичної влади, нерозвинутістю соціальних мереж (виняток - мережі засновані на близькоспоріднених зв'язках, непотизмі). Причинами такого стану речей $є$ також відсутність традицій відповідальності, зобов'язань, участі [2, с. 87].

Таким чином, довіра є тим значущим механізмом, який здатен забезпечити формування ефективних взаємовідносин, діалогів, актів вирішення гострих суспільних суперечностей, а також участь суб'єктів і в державно-політичній, і в соціально-духовній сферах людського існування, що буде впливати на досягнення вищої якості життя. Тема довіри в громадянському суспільстві, особливо інституційної, $є$ гострою для українського соціуму, відтак пошук шляхів забезпечення високого рівня довіри до влади стає запорукою ефективної реалізації інтересів громадян.

\section{Література:}

1. Кучабський О.Г., Погорєлий С.С. Довіра до органів публічної влади як ключовий фактор ефективності системи державного управління. Публічне управління: теорія та практика, 2013. С. 103-108. 
2. Макух О.С. Довіра як атрибут громадянського суспільства: комунікативний аспект. Вісник НТУУ» КПІ» Політологія. Соиіологія. Право, 2014. - С. 85-89.

3. Концепція розвитку системи надання адміністративних послуг органами виконавчої влади - https://www.kmu.gov.ua/npas/29277890

DOI https://doi.org/10.30525/978-9934-588-92-1-54

\title{
ПСИХОЛОГІЧНЕ НАСИЛЬСТВО ЯК ОДНА 3 ФОРМ БУЛІНГУ УЧАСНИКІВ ОСВІТНЬОГО ПРОЦЕСУ
}

\author{
Градова Ю. В. \\ кандидат юридичних наук, доиент, \\ дочент кафедри конституційного і муніципального права \\ Харківського національного університету імені В. Н. Каразіна \\ м. Харків, Україна
}

Насильство в закладах освіти має різну природу i характер, проявляється як у формі одноразових насильницьких дій, так i у вигляді постійних знущань, принижень і систематичного цькування (булінг), яке становить особливу небезпеку. Булінг (від англ. bully хуліган, задирака, грубіян, "to bully" - задиратися, знущатися) тривалий процес свідомого жорстокого ставлення, агресивної поведінки, щоб заподіяти шкоду, викликати страх, тривогу або ж створити негативне середовище для людини [2].

Кожен здобувач освіти має право на захист під час освітнього процесу від приниження честі та гідності, будь-яких форм насильства та експлуатації, булінгу (цькування), дискримінації за будь-якою ознакою, пропаганди та агітації, що завдають шкоди здоров'ю [1]. Згідно Закону України «Про освіту» здійснення булінгу учасників освітнього процесу $є$ можливим у формі психологічного, фізичного, економічного, сексуального насильства, у тому числі із застосуванням засобів електронних комунікацій (кібербулінг) [3]. У науці розрізняють прямий та непрямий булінг. Прямий булінг має місце, коли стосовно жертви вчиняються такі дії як: штовхання, ляпаси, удари, щипання, кусання; а непрямий булінг передбачає бойкотування, ігнорування, принижуючі жести та погляди тощо. Прямий булінг є більш поширеним в молодших класах, а непрямий - в середніх [4, с. 467]. 